\title{
Liquid segregation parameters from amphibolite dehydration melting experiments
}

\author{
Michael B. Wolf ${ }^{1}$ and Peter J. Wyllie \\ Division of Geological and Planetary Sciences, California Institute of Technology, Pasadena
}

\begin{abstract}
We have experimentally obtained some of the parameters necessary for understanding the segregation of silicate liquid from amphibolite undergoing dehydration melting at $1 \mathrm{GPa}$ and $750-1000^{\circ} \mathrm{C}$. The solidus for this calcic amphibolite $(68 \% \mathrm{Mg}-\mathrm{Hb}, 32 \% \mathrm{Pl}$ $\left.\left(A n_{90}\right)\right)$ is $<750^{\circ} \mathrm{C}$. Amphibolites begin to melt at relatively high temperatures in the garnetabsent field, but the solidus appears to backbend at $\sim 1 \mathrm{GPa}$, coincident with the garnet-in boundary. Hornblende breakdown due to garuet formation releases $\mathrm{H}_{2} \mathrm{O}$ and causes melting. Thus, in the garnet-present field ( $21 \mathrm{GPa}$ ), the amphibolite dehydration melting solidus may be coincident with the $\mathrm{H}_{2} \mathrm{O}$-saturated solidus. Liquid interconnectivity may be achieved at $<900^{\circ} \mathrm{C}$ and $<5$ vol \% liquid, based on both physical and chemical data from solid rock runs. Mass balance calculations from powdered rock runs suggest that small amounts $(\sim 5-15 \mathrm{vol} \%)$ of hydrous ( $\geq 4 \mathrm{wt} \% \mathrm{H}_{2} \mathrm{O}$ ), low-viscosity $\left(10^{3}-10^{4} \mathrm{~Pa} \mathrm{~s}\right)$, heavy rare earth element-depleted, felsic liquid may be segregated during amphibolite dehydration melting at $2875^{\circ} \mathrm{C}$. The rapid breakdown of coarse-grained $\mathrm{Hb}$ cores may lead to the formation of transient $\mathrm{H}_{2} \mathrm{O}$-saturated liquids with even lower viscosities $\left(\sim 10^{2} \mathrm{~Pa} \mathrm{~s}\right)$. Although comprising only a small portion of the melting cycle, these $\mathrm{H}_{2} \mathrm{O}$-rich conditions may enhance the segregation of liquid by reduction of liquid viscosities and by mechanical effects on the restite (e.g., increased deformation and liquid fracturing). During anatexis of coarse-grained (natural) rocks, transient conditions may control the initial stages of liquid segregation.
\end{abstract}

\section{Introduction}

Petrologists have long recognized the potential role of amphibolite melting in the genesis of tonalites, trondhjemites and granodiorites [e.g., Barker, 1979]. Although the phase relationships of amphibolites undergoing dehydration melting are critical in determining the conditions of granitoid liquid formation, detailed experimental studies have only recently addressed these problems [e.g., Beard and Lofgren, 1991; Rapp et al., 1991; Rushmer, 1991; Winther and Newton, 1991; Wolf and Wyllie, 1991, 1994]. Wyllie and Wolf [1993] and Wolf and Wyllie [1994] have shown that lower continental crustal temperatures need not be unreasonably high to produce granitoid liquids during amphibolite dehydration melting. Thus one major barrier to the amphibolite-tonalite connection has fallen. However, a question of scale still remains, in that this melting process can produce migmatites and small bodies of magma but does not appear to be able to produce large granitoid plutons along most current crustal geothermal gradients. In certain cases, though, granitoid plutons have been shown to be composed of a conglomeration of many small batches of liquid [e.g., Deniel et al., 1987].

Another piece of experimental evidence supports the geochemists' and geologists' arguments for the connection, namely, that garnet generally should be part of the restite from which heavy rare earth element (HREE) -depleted silicate liquids

\footnotetext{
${ }^{1}$ Now at School of Geology and Geophysics, University of Oklahoma, Norman.

Copyright 1995 by the American Geophysical Union.

Paper number 95JB00660.

0148-0227/95/95JB-00660\$05.00
}

have been extracted [e.g., Arth and Barker, 1976]. Experiments show that garnet does play a major role in determining the REE character of the liquids produced during amphibolite dehydration melting above 1 GPa [Rapp et al., 1991; Wolf and Wyllie, 1993, 1994]. Relative rates of garnet growth and subsequent rehomogenization control compositional zoning in garnets which may give clues to the conditions during liquid segregation.

The production of these liquids is necessary but not sufficient for the formation of large bodies of tonalite. Once produced, the liquids must segregate from the source rock (now restite) and coalesce in dikes, veins, and/or plutons during ascent. This segregation process is controlled by parameters such as liquid fraction and time versus temperature relationships, water contents and viscosities of liquids, liquid interconnectivity, and strain rates within the amphibolitic source. An interconnected liquid network must form for segregation to occur, regardless of liquid viscosity. Once such a network has formed, though, a low liquid viscosity ( $\leqslant 10^{4} \mathrm{~Pa} s$ ) is required for liquid segregation over reasonable geological times $\left(10^{6} \mathrm{~m} . \mathrm{y}\right.$.). The viscosity, in turn, is controlled by temperature and liquid composition (especially $\mathrm{H}_{2} \mathrm{O}$ content). Wolf and Wyllie [1991] have suggested that lowviscosity liquids can become interconnected at relatively low temperatures during amphibolite dehydration melting. Thus all of the necessary conditions appear to have been met for the generation of tonalitic bodies by the dehydration melting of lower crustal amphibolite. This paper synthesizes our previous results [Wolf and Wyllie, 1991, 1993, 1994] and focuses on the physical nature of amphibolite-derived liquids.

\section{Experimental and Analytical Methods}

Details of the starting materials, experimental conditions, and analytical methods are discussed by Wolf and Wyllie [1991, 1994] and Wolf [1992]. Both solid rock cores and finely ground 
powders of a natural, calcic low-K amphibolite were used in piston-cylinder experiments at $1 \mathrm{GPa}, 750-1000^{\circ} \mathrm{C}, f \mathrm{O}_{2} \sim \mathrm{Ni}$ $\mathrm{NiO}$, for 1-9 days. The rock is composed of $67.4 \mathrm{vol} \%$ magnesio-hornblende, $32.5 \mathrm{vol} \%$ anorthitic plagioclase ( $\left.A n_{90}\right)$ and 0.1 vol \% sphene (no garnet), with a whole rock composition in weight percent of $\mathrm{SiO}_{2}=48.5 ; \mathrm{TiO}_{2}=0.4 ; \mathrm{Al}_{2} \mathrm{O}_{3}=14.4 ; \mathrm{FeO}$ = 8.5; $\mathrm{MnO}=0.2 ; \mathrm{MgO}=10.8 ; \mathrm{CaO}=14.8 ; \mathrm{Na}_{2} \mathrm{O}=1.7 ; \mathrm{K}_{2} \mathrm{O}=$ 0.2. $\mathrm{No}_{2} \mathrm{O}$ was added to the $\mathrm{Au}$ capsules other than that structurally bound in the hydrous amphibole.

\section{Results}

\section{Phase Relationships}

This paper focuses primarily on the physical nature of amphibolite-derived liquids. However, the segregation story would not be complete without a discussion of the phase relationships of the mineral assemblages, the restite, from which some liquids might escape, because of their control on melting reactions and liquid compositions. Two important characteristics of the amphibolite used in our experiments are the very low temperature solidus $\left(<750^{\circ} \mathrm{C}\right)$ and the formation of garnet at 1 $\mathrm{GPa}$. A generalized reaction for the entire interval of melting can be expressed as hornblende $(\mathrm{Hb})+$ plagioclase $(\mathrm{Pl}) \rightarrow$ clinopyroxene $(\mathrm{Cpx})+$ liquid $(\mathrm{Liq})+$ Garnet $(\mathrm{Ga})+$ aluminous hornblende $(\mathrm{Al}-\mathrm{Hb})+$ orthopyroxene $(\mathrm{Opx})$, with $\mathrm{Cpx}, \mathrm{Ga}$ and Liq as the major products of the reaction. Because of the complexities of the reaction and phase compositions, the reaction stoichiometry is not uniquely definable through mass balance calculations and is not reported. Figure $1 \mathrm{a}$ is an ACF deluxe diagram (a modified $\mathrm{Al}_{2} \mathrm{O}_{3}-\mathrm{CaO}-\mathrm{FeO}$ diagram) on which is plotted the liquid compositions along with representative analyses of all of the minerals present throughout the amphibolite dehydration melting temperature interval of the experiments [after Thompson, 1988]. Qualitative reaction progress within the partially melted amphibolite can be visualized in the series of ACF diagrams arranged by temperature (Figure 1b), which might represent changes in the mineral assemblage of the amphibolite under prograde conditions through ultrametamorphism and migmatization. Even though a silicate liquid is present in all of the runs, the changes in mineralogy that take place in the experiments can be described by the metamorphic reactions that separate the amphibolite facies from the pyroxene granulite facies (plus liquid). Figures 2a-2c depict the amphibolite faciespyroxene granulite facies transition in ACF space, showing the breakdown of hornblende and expansion of the orthopyroxene field [from Robinson, 1982]. Figure 2d combines the effects of solid solutions with the amphibolite facies-to-pyroxene granulite facies diagrams (Figures $2 \mathrm{~b}$ and $2 \mathrm{c}$ ) to show the mineral assemblage present in most of the amphibolite melting experiments; hornblendes of different compositions coexisting with plagioclase, clinopyroxene, orthopyroxene and garnet (plus liquid). Thus the ACF diagrams are as useful in gauging the qualitative progress of reaction during dehydration melting as they are during metamorphism.

Wyllie and Wolf [1993] and Wolf and Wyllie [1994] concluded that the breakdown of hornblende and subsequent formation of garnet at pressures $\geq 1 \mathrm{GPa}$ may strongly depress the temperature of the solidus, possibly down to the $\mathrm{H}_{2} \mathrm{O}$-saturated solidus; the $\mathrm{H}_{2} \mathrm{O}$ liberated from the hornblende is not incorporated into the growing garnet but, instead, reacts with the plagioclase to form liquid. Figure 3 is a pressure-temperature diagram showing the phase relationships relevant for amphibolite dehydration melting (based on work by Lambert and Wyllie [1972], Wyllie and Wolf [1993]. Wolf and Wyllie [1994]). Three features of this diagram important for this discussion are the $\mathrm{H}_{2} \mathrm{O}$-saturated basalt solidus, the garnet-in (Ga-in) boundary for mafic rocks, and the shape of the dehydration melting region (lightly shaded region between $A B C D E F$ ). The Ga-in boundary is shown as a univariant line,

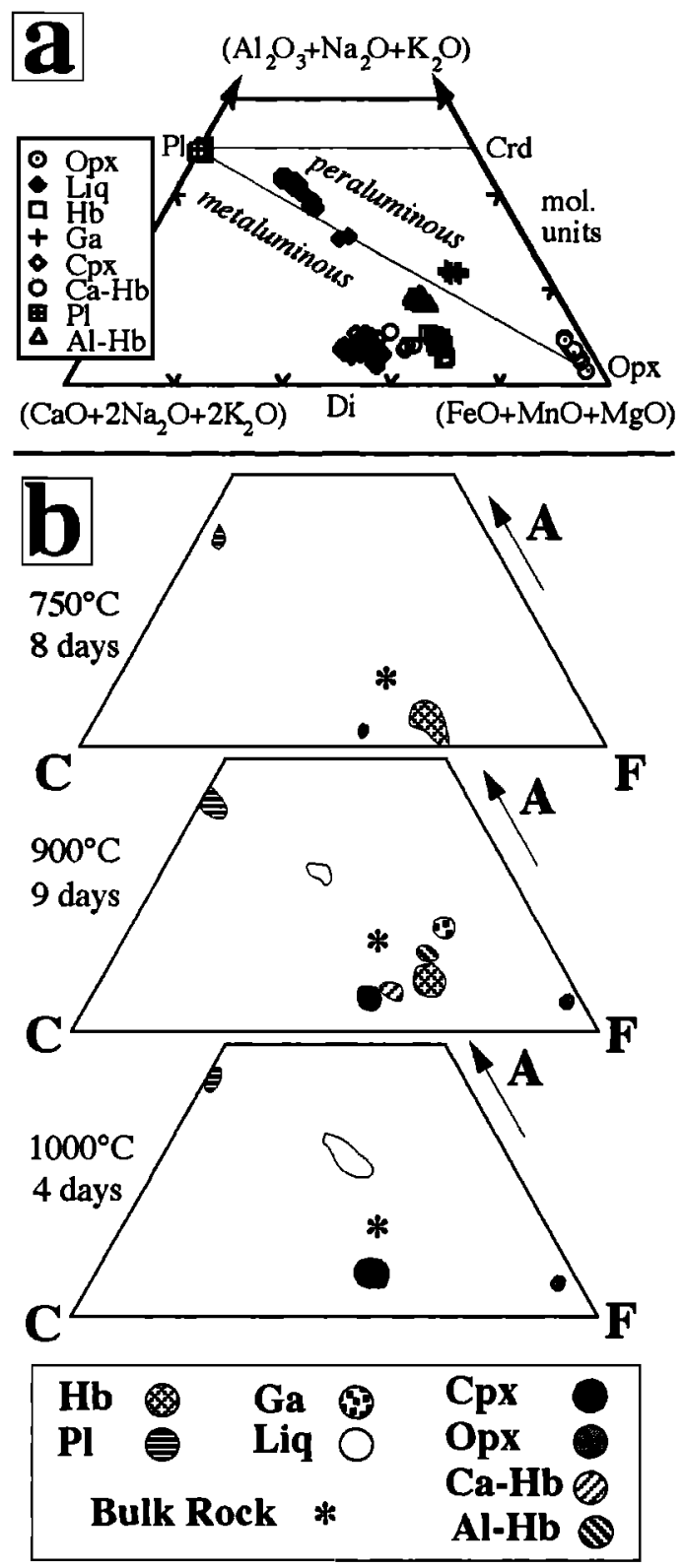

Figure 1. Liquid and mineral compositions from powdered amphibolite runs at $1 \mathrm{GPa}$. (a) An ACF-deluxe projection (a modified $\mathrm{Al}_{2} \mathrm{O}_{3}-\mathrm{CaO}-\mathrm{FeO}$ diagram) of compositions from throughout the melting interval, $750-1000^{\circ} \mathrm{C}$, visually represents the generalized reaction, $\mathrm{Hb}+\mathrm{Pl} \rightarrow \mathrm{Liq}+\mathrm{Cpx}+$ new $\mathrm{Hb}+\mathrm{Ga}+$ Opx [after Thompson, 1988]. Most of the liquids are mildly peraluminous, but high-temperature liquids are metaluminous. Crd, corundum; Di, diopside; Pl, plagioclase; Opx, orthopyroxene; $\mathrm{Hb}$, hornblende (initial, or new calcic or aluminous); Liq, liquid; Cpx, clinopyroxene; Ga, garnet. (b) A series of conventional ACF diagrams arranged in order of increasing temperature (top to bottom); $\mathrm{A}, \mathrm{Al}_{2} \mathrm{O}_{3} ; \mathrm{C}, \mathrm{CaO} ; \mathrm{F}$, $\mathrm{FeO}$. See Figure 2 for comparison with high-grade metamorphic phase assemblages. 

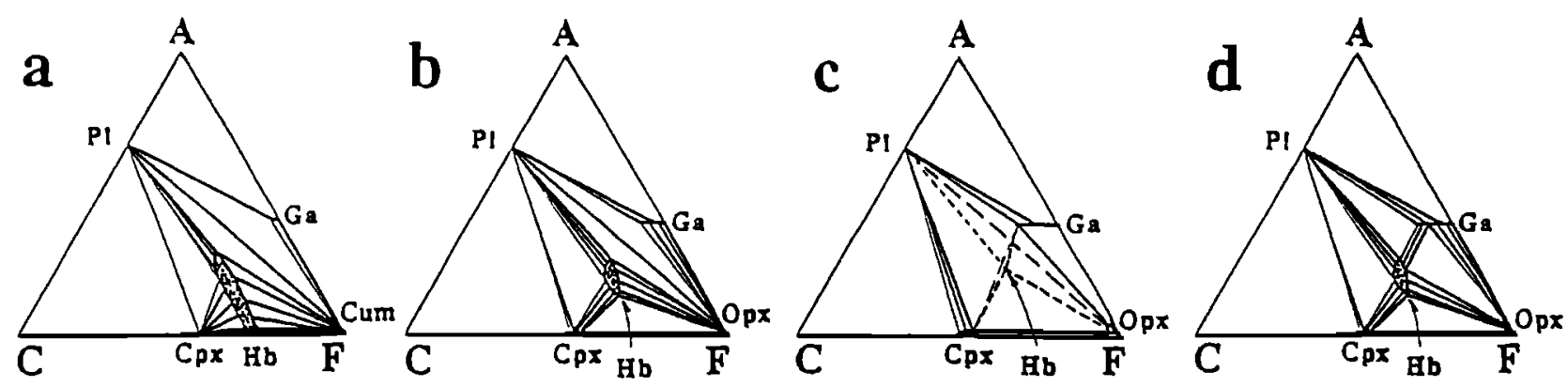

Figure 2. ACF diagrams show typical phase relationships (iron-rich systems) in (a) the amphibolite facies (Cum, cummingtonite); (b) the amphibolite facies-pyroxene granulite facies transition; and (c) the pyroxene granulite facies [after Robinson, 1982]. (d) The liquid-present experimental results from Figure 1 are portrayed in the ACF framework of subsolidus phase relationships using Figure $2 b$ and $2 c$ tie lines.

but its actual position and shape are strongly dependent on bulk composition. The amphibolite dehydration melting region can be divided into two parts based on the location of the beginning of hornblende dehydration melting: a narrow high-temperature/lowpressure region (ABDE) and a wide low-temperature/highpressure region (BCEF). The near-vertical, hightemperature/low-pressure and low-temperature/high-pressure dehydration melting solidi are connected along a near-horizontal backbent solidus segment that corresponds with the Ga-in boundary (slight positive slope) appropriate for and strongly dependent on the composition of the amphibolite. Thus the curve $(\mathrm{ABCF})$ defines the entire amphibolite dehydration melting solidus.

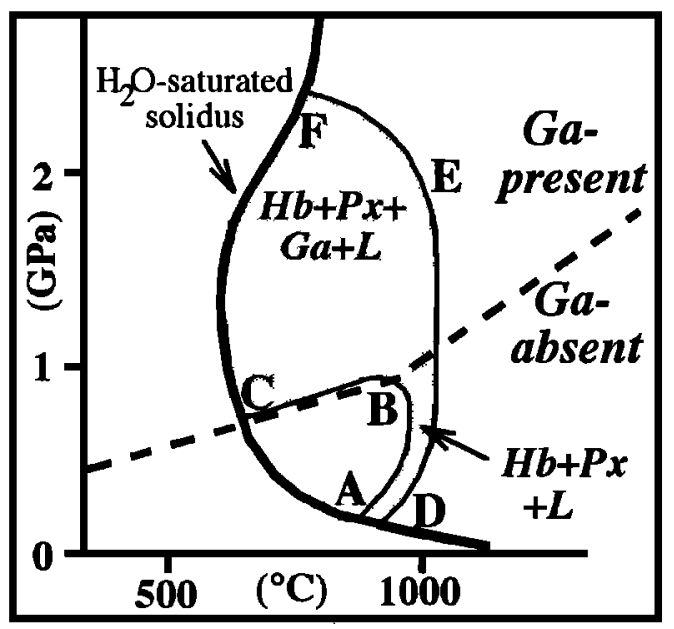

Figure 3. Generalized amphibolite melting relationships as a function of pressure and temperature from Wyllie and Wolf [1993] and Wolf and Wyllie [1994], following Lambert and Wyllie [1972]. The light-shaded area (ABCDEF) is the reaction interval for hornblende $(\mathrm{Hb})$. The dashed line is the garnet-in (Ga-in) boundary, the heavy solid curve is the $\mathrm{H}_{2} \mathrm{O}$-saturated basalt solidus. The hornblende reaction interval consists of two parts, the narrow, low-P/high-T band (ABDE) where pyroxene $(\mathrm{Px})$ is the main mineral product, and the broad, low-T/high-P band (BCEF) where garnet and jadeitic pyroxene are the breakdown products. For fully hydrated amphibolite $(\mathrm{Hb}+\mathrm{Pl})$ in a closed system, the dehydration melting solidus at pressures $\geq 1$ $\mathrm{GPa}(\mathrm{BC})$ may be as low as $(\mathrm{CF})$, coincident with the $\mathrm{H}_{2} \mathrm{O}$ saturated solidus.
The actual solidus temperature for the amphibolite used in this study has not been determined but is between 650 and $750^{\circ} \mathrm{C}$ at 1 $\mathrm{GPa}$; the dehydration melting solidus segment $(\mathrm{CF})$ may lie as low as the $\mathrm{H}_{2} \mathrm{O}$-saturated solidus but may be higher if an amphibolite is not fully hydrated (i.e., if the amphibole contains less than the maximum amount of structurally bound $\mathrm{OH}$, e.g., $\mathrm{F}$ or $\mathrm{Cl}$ present, or if other nonhydrous mafic minerals are present). In addition, the amphibole composition may change during metamorphism via solid solution substitutions, which can affect the stability of the amphibole (relative to the melting process) and thus the temperature of the solidus; however, it is unclear whether changes in certain amphibole compositional parameters (e.g., $\mathrm{Fe}, \mathrm{Mg}, \mathrm{Ca}$, or $\mathrm{Ti}$ ) directly affect amphibole $\mathrm{OH}$ contents and thus the amount of liquid that can be produced by breakdown of the amphibole. Further research is needed to assess the effect of "volatile" constituents on amphibole stability and melting relationships.

Although the garnet-present amphibolite dehydration melting solidus may be hundreds of degrees lower than the garnet-absent (lower pressure) solidus, the amount of liquid formed near the higher-pressure lower-temperature segment ( $\geq 1 \mathrm{GPa})$ will be quite small. Figure 4 is a temperature versus liquid fraction diagram showing the results from various amphibolite and basalt melting experiments. Our experiments (bold line) suggest that the temperatures of the dehydration melting solidi may approach those of the $\mathrm{H}_{2} \mathrm{O}$-saturated solidi, if garnet is produced. If viewed from the high-temperature side, $\mathrm{H}_{2} \mathrm{O}$-saturated melting curves are somewhat concave, but dehydration melting curves are somewhat convex (i.e., at low $\mathrm{T}, \mathrm{dX}_{\mathrm{L}} / \mathrm{dT}_{\left[\mathrm{H}_{2} \mathrm{O} \text {-sat] }\right.}>\mathrm{dX}_{\mathrm{L}} / \mathrm{dT}[\mathrm{d}$-m]. but at high $\mathrm{T}, \mathrm{dX}_{\mathrm{L}} / \mathrm{dT}_{\left[\mathrm{H}_{2} \mathrm{O} \text {-sat] }\right.}<\mathrm{dX}_{\mathrm{L}} / \mathrm{dT}_{\text {[d-m] }}$, where $\mathrm{X}_{\mathrm{L}}$ is the liquid fraction and $\mathrm{T}$ is the temperature). Temperatures in excess of $825^{\circ} \mathrm{C}$ are needed to produce $>10$ vol \% liquid during dehydration melting (at $0.7-1.0 \mathrm{GPa}$ ) but would produce $>25-50$ vol \% liquid during $\mathrm{H}_{2} \mathrm{O}$-saturated melting (at $0.5 \mathrm{GPa}$ ). However, as discussed below, liquid segregation might occur at liquid fractions $<10 \mathrm{vol} \%$, and thus at temperatures $<825^{\circ} \mathrm{C}$.

A natural analog provides evidence for the soundness and relevancy of our experimental results. From field and thermobarometric work on a large mafic dike swarm within the northern Canadian Chipman batholith, Williams and Hanmer [1994] concluded that garnet-producing amphibolite anatexis occurred at conditions of $800-900^{\circ} \mathrm{C}$ and $1 \mathrm{GPa}$. The malic rocks are similar in composition to the amphibolite used in our experiments (M. L. Williams, personal communication, 1994), and when they partially melted, they generated enough liquid in some regions to form an interconnected network of liquid. 


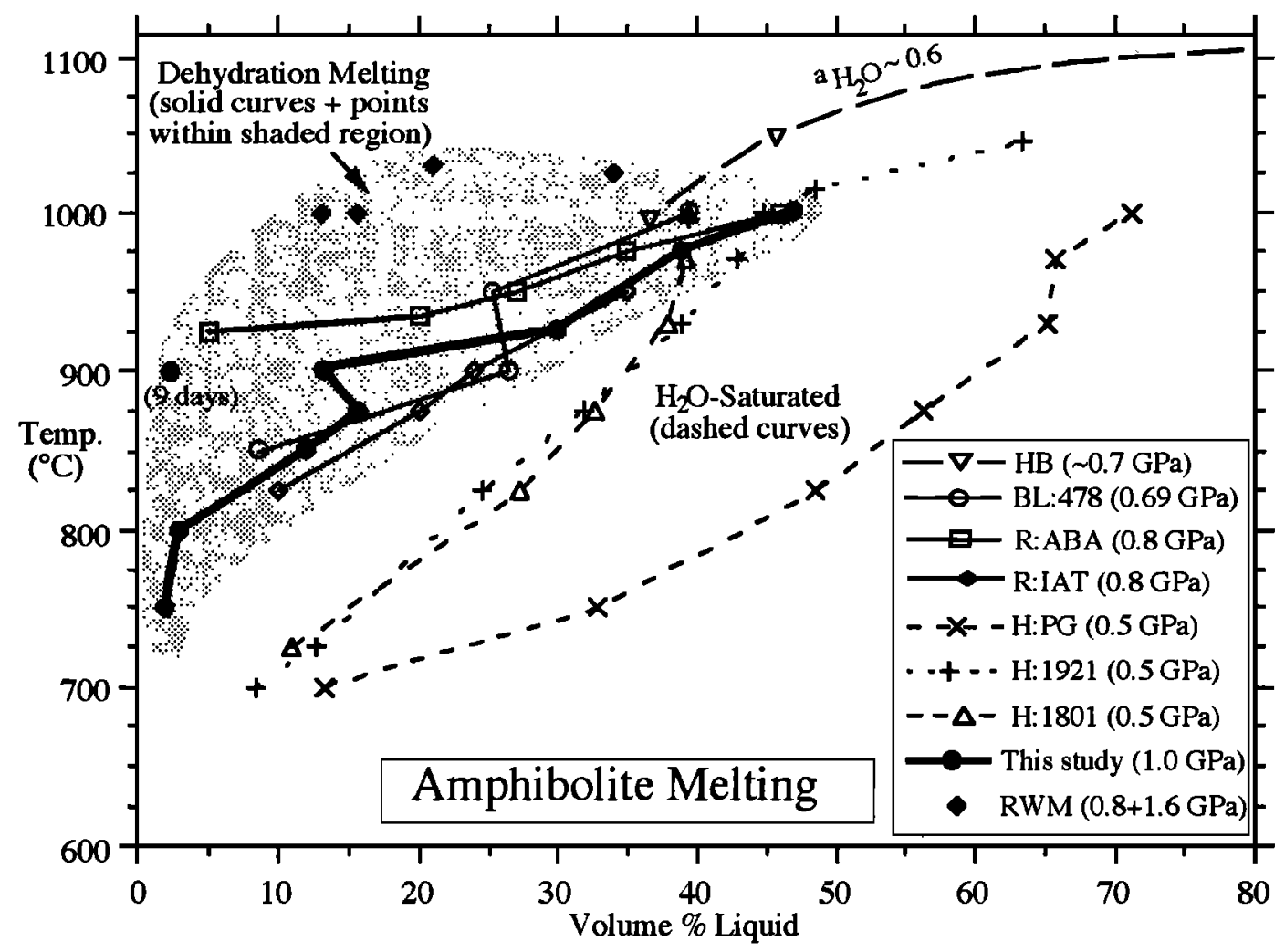

Figure 4. Volume percents of liquids produced in various amphibolite and basalt melting experiments as a function of temperature. Dehydration melting (solid curves and points within shaded region) produces less liquid at a given temperature than $\mathrm{H}_{2} \mathrm{O}$-saturated melting (dashed curves). Our results differ from those of the other dehydration melting experiments by (a) melting at lower temperatures and (b) exhibiting a reversal in the trend between $875^{\circ} \mathrm{C}$ and $900^{\circ} \mathrm{C}$. Sources are HB, Holloway and Burnham [1972]; BL, Beard and Lofgren [1991]; R, Rushmer [1991]; H, Helz [1976]; this study [Wolf and Wyllie, 1994], 8/9- and 4-day runs; RWM, Rapp et al. [1991]. Data from the literature converted from weight percent to volume percent liquid using compositionally dependent density equations from Shaw [1972], which increases the percentage of liquid by $\sim 10 \%$ at higher liquid fractions [Wolf, 1992] (Rushmer's [1991] results were already in volume percent); this conversion makes for more useful interpretations relevant to the rheological behavior and segregation of the liquids.

Further work on these rocks may reveal details of the relationship between liquid fraction and temperature.

\section{$\mathrm{H}_{2} \mathrm{O}$ Contents and Viscosities of the Liquids}

Wolf and Wyllie [1991] discussed how the disequilibrium effect of the differential rates of hornblende breakdown and liquid formation can lead to low-temperature, $\mathrm{H}_{2} \mathrm{O}$-rich, lowviscosity liquids in the natural (relatively coarse-grained), solid rock samples from the experiments. The $\mathrm{H}_{2} \mathrm{O}$ content of the liquids might be even greater than the $\mathrm{H}_{2} \mathrm{O}$-rich estimates calculated from fine-grained powder experiments that are nearer to equilibrium (below). The extent to which this effect occurs in nature depends on the rate of heating above the solidus. During rapid heating, a transient vapor phase might be generated because the location of hornblende breakdown (within homblende grains) does not coincide with the location of liquid formation (along hornblende-plagioclase boundaries) [Wolf and Wyllie, 1991, Figure 6]. Mass balance calculations suggested that the liquids produced during dehydration melting can be relatively hydrous. Liquid viscosities were calculated based on an analyzed liquid composition (for non- $\mathrm{H}_{2} \mathrm{O}$ components) and a range of arbitrary $\mathrm{H}_{2} \mathrm{O}$ contents and temperatures [Wolf and Wyllie, 1991, Table 4]; at $875^{\circ} \mathrm{C}$, viscosities range from $5 \times 10^{7} \mathrm{~Pa}$ s (dry) to $50 \mathrm{~Pa} \mathrm{~s}(11$ wt $\% \mathrm{H}_{2} \mathrm{O}$ ). Viscosities were also calculated (using mass balance-constrained liquid compositions, see below) for the experiments that used finely ground amphibolite powder and, between $875^{\circ} \mathrm{C}$ and $975^{\circ} \mathrm{C}$, were in the $10^{3}-10^{4} \mathrm{~Pa}$ s range.

More recent quantitative microprobe imaging of some of these runs has given us more accurate estimates of the liquid fractions from the powder experiments [Wolf and Wyllie, 1994, BSE data in Table 2], experiments that are closer to equilibrium, relative to the solid rock experiments. Figure 5 plots the calculated amount of $\mathrm{H}_{2} \mathrm{O}$ (weight percent) in the liquid versus the measured amount of liquid. The ratio of the amount of hornblende that breaks down versus the amount of liquid that forms controls the quantity of $\mathrm{H}_{2} \mathrm{O}$ that is added to the liquid (homblende and liquid being the only hydrous phases in the system). The large arrows outline the general trend of the data with increasing temperature. As $15-45 \%$ of the hornblende breaks down up to $900^{\circ} \mathrm{C}$, the $\mathrm{H}_{2} \mathrm{O}$ content of the liquids exceeds $4 \mathrm{wt} \%$ and possibly may rise over $7 \mathrm{wt} \%$. With increasing temperature, though, the amount of liquid increases rapidly, and the $\mathrm{H}_{2} \mathrm{O}$ content is steadily reduced down to 2 wt $\%$ at $1000^{\circ} \mathrm{C}\left(\mathrm{X}_{\mathrm{L}} \sim 47 \mathrm{vol} \%\right)$, which is similar to the value determined by Rushmer [1991] at $0.8 \mathrm{GPa}$ and $1000^{\circ} \mathrm{C}$.

These $\mathrm{H}_{2} \mathrm{O}$ contents have been used to calculate liquid viscosities using Shaw's [1972] empirical equations; between 


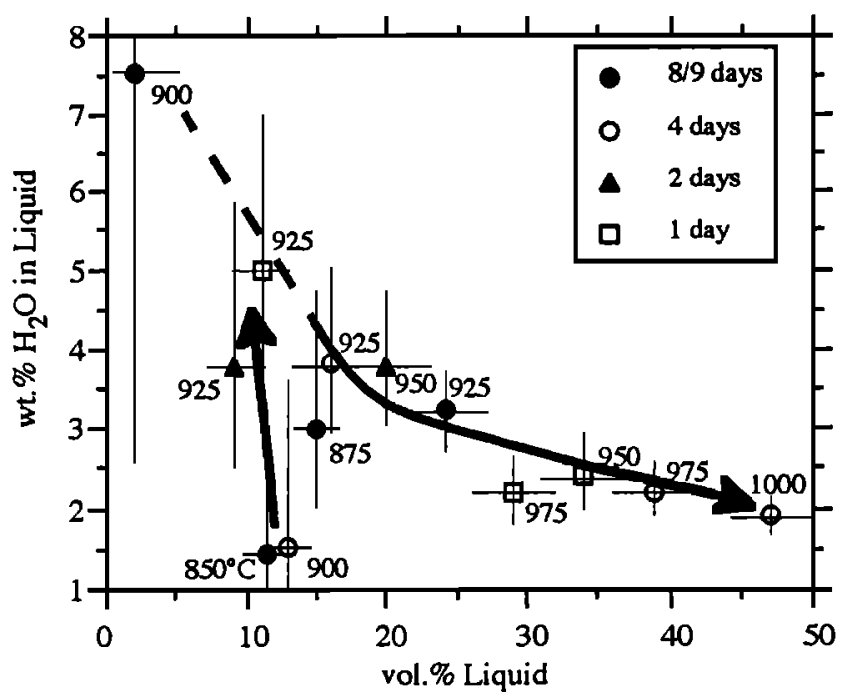

Figure 5. Calculated weight percent $\mathrm{H}_{2} \mathrm{O}$ in liquid versus measured volume percent liquid from the powdered amphibolite dehydration melting runs (calculated by mass balance assuming all hornblendes contain 2 wt $\% \mathrm{H}_{2} \mathrm{O}$ ). At $875^{\circ} \mathrm{C}$, with widespread breakdown of hornblende and little increase in liquid fraction, the amount of $\mathrm{H}_{2} \mathrm{O}$ in the liquid rises to $\geq 4 \mathrm{wt} \%$ (thick arrow pointing up). With increasing liquid fractions, the amounts of dissolved $\mathrm{H}_{2} \mathrm{O}$ decrease to $\sim 2$ wt $\%$ at $\mathrm{X}_{\mathrm{L}} \sim 0.5$ at $1000^{\circ} \mathrm{C}$ (thick arrow pointing down).

875 and $975^{\circ} \mathrm{C}$, the viscosities range from $4 \times 10^{4}$ to $10^{3} \mathrm{~Pa} \mathrm{~s}$ (Figure 6). Note that these viscosities are maximum values (for a given temperature) from the near-equilibrium powdered amphibolite runs; liquid viscosities in natural systems may be even lower due to the disequilibrium effects of the differential rates of homblende breakdown and liquid formation [Wolf and Wyllie, 1991] (also discussed below).

We conclude that amphibolite dehydration melting can produce small amounts of liquid ( $\leq 5 \mathrm{vol} \%)$ at relatively low temperatures (normal lower crustal conditions) and the liquids that form can be relatively $\mathrm{H}_{2} \mathrm{O}$-rich, with low viscosities. However, an interconnected liquid network must form, either by crystallographic control or fracture formation, for segregation to occur, regardless of liquid viscosity.

\section{Liquid Interconnectivity}

In experimental studies focused on the liquid morphology of partially melted fine-grained mineral powders, much has been said on the importance of the interfacial energy-controlled dihedral angle for liquid interconnectivity (with a dihedral angle, the angle between two liquid-filled crystal faces, of $\angle 60^{\circ}$ needed for interconnectivity) [e.g., Watson, 1982; Waff and Bulau, 1982; Jurewicz and Watson, 1984]. However, Bulau et al. [1979] noted that the interfacial energy-controlled textural adjustment occurs only in the absence of anisotropic minerals. In contrast to the earlier studies, Wolf and Wyllie [1991] concluded that in partially melted coarser-grained solid amphibolite, the liquid morphology is crystallographically controlled due to the surface energy anisotropy of the hornblende-dominated system. In our experiments, liquid formation along cleavage planes leads to liquid pools with blocky, angular morphologies along most hornblende-plagioclase boundaries, resulting in relatively wide slabs of interconnected liquid along intergranular crystal surface planes, not the liquid-filled tetrahedronally shaped junctions joined by narrow prismatic tubules of the interfacial energycontrolled systems. Brief descriptions of the liquid morphologies from three experiments $\left(850^{\circ} \mathrm{C}, 875^{\circ} \mathrm{C}\right.$ and $\left.900^{\circ} \mathrm{C}\right)$ from Wolf and Wyllie [1991] follow and are keyed to drawings taken from photomicrographs of the run products (Figure 7):

In the $850^{\circ} \mathrm{C}, 21$-day run (Figure $7 \mathrm{a}$ ), $\sim 1 \%$ liquid forms within hornblende embayments along hornblende/plagioclase ( $\mathrm{Hb} / \mathrm{PI})$ boundaries but does not coat these boundaries continuously. A smaller amount of liquid in isolated pockets within hornblende grains is likely associated with $\mathrm{Hb} / \mathrm{Pl}$ boundaries in the third dimension. The liquid forms irregular-shaped polygonal pockets ranging in size from 5 to $20 \mu \mathrm{m}$. Many have crystallographically controlled corners with angles that range from approximately $30^{\circ}$ to $120^{\circ}$, with most apparent angles $>60^{\circ}$. Many of the pocket edges are straight, from corner to corner, showing little of the curvature which is typically found along the lengths of liquid pocket edges with simple dihedral angles as in partial melting experiments using powders [Bulau et al., 1979; Jurewicz and Watson, 1984]. Some of the corners have curved boundaries, but classical dihedral angles are not evident. Whether these angles would develop in longer runs remains to be determined. Although using biotite- and amphibole-rich powders, D. LaPorte and E. B. Watson (E. B. Watson, personal communication, 1991) found textural features similar to our flat crystal/liquid surfaces.

In the $875^{\circ} \mathrm{C}, 14$-day run, the liquid comprises $\sim 2 \%$ of the rock and almost surrounds the plagioclase grains (Figure $7 \mathrm{~b}$ ). The liquid at $\mathrm{Hb} / \mathrm{Pl}$ boundaries is interconnected along the lengths of the plagioclase grains in two dimensions, and it appears to make inroads along the cleavages of hornblendes. Between $850^{\circ} \mathrm{C}$ and $875^{\circ} \mathrm{C}$, individual liquid pockets within hornblende grains and along $\mathrm{Hb} / \mathrm{PI}$ boundaries grow larger (30-100 $\mu \mathrm{m}$ lengths), and the pocket edges lose their straightness. They are more curved than at $850^{\circ} \mathrm{C}$, with longer edges of the pockets typically scalloped by many cusps protruding along possible cleavage traces into the hornblende. The smaller pockets $(<20 \mu \mathrm{m})$, however, have corners bounded by straight edges. The majority of crystallographically controlled angles are $>60^{\circ}$.

In the $900^{\circ} \mathrm{C}, 14$-day run, the liquid comprises $\sim 5 \%$ of the rock (Figure 7c); half of the liquid is associated with $\mathrm{Hb} / \mathrm{PI}$ boundaries, and half is commonly in approximately linear

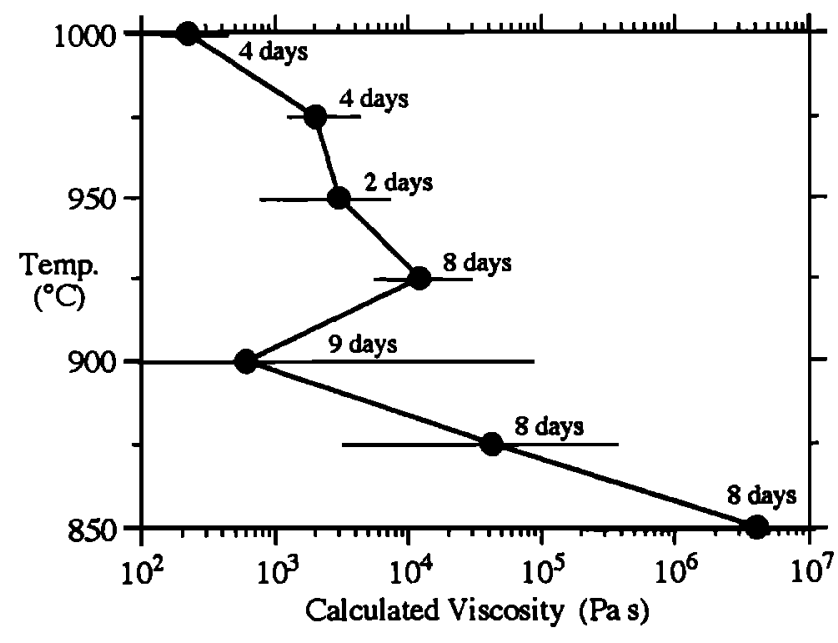

Figure 6. Calculated liquid viscosities [after Shaw, 1972] derived from powdered amphibolite dehydration melting runs as a function of temperature [see Wolf, 1992; Wolf and Wyllie,1991]. 


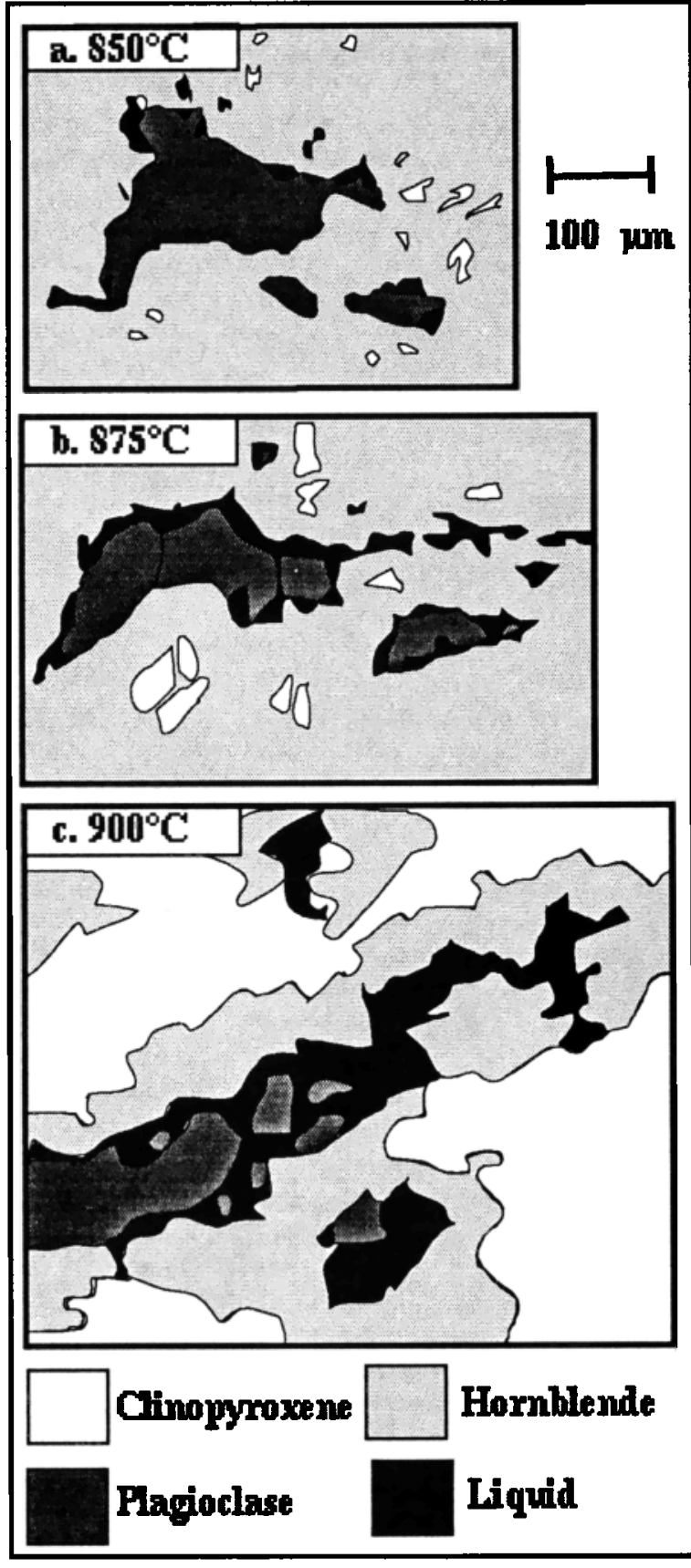

Figure 7. Drawings from photomicrographs of solid amphibolite runs showing the textural development of liquid morphologies during rapid amphibolite dehydration melting at $1 \mathrm{GPa}$. (a) $850^{\circ} \mathrm{C}, 21$ days, $\sim 1$ vol $\%$ liquid; (b) $875^{\circ} \mathrm{C}, 14$ days, $\sim 2$ vol $\%$ liquid: (c) $900^{\circ} \mathrm{C}, 14$ days, $\sim 5$ vol \% liquid. Liquids appear interconnected along hornblende/plagioclase boundaries at $\geq 875^{\circ} \mathrm{C}$.

extensions of $\mathrm{Hb} / \mathrm{PI}$ liquid pockets. The shapes of the liquid pockets are flat-faced, irregular polyhedra, regardless of pocket size (10-70 $\mu \mathrm{m}$ lengths). The liquid pocket corners generally follow the prism faces of the hormblende crystals.

On the basis of these straightforward textural observations, Wolf and Wyllie [1991] concluded that liquid interconnectivity probably was achieved in the $875^{\circ} \mathrm{C}$ and $900^{\circ} \mathrm{C}$ amphibolite rockmelting experiments. Additional evidence for interconnectivity at $875^{\circ} \mathrm{C}$ and $900^{\circ} \mathrm{C}$ comes from the unique glass compositions from these samples; high $\mathrm{Na}_{2} \mathrm{O}$ contents ( $\sim 8 \mathrm{wt} \% ; 4 \times$ normal) in the glass throughout the samples indicated that sodium from the $\mathrm{NaCl}$ pressure medium outside of the capsules contaminated the liquids and infiltrated the interconnected liquid networks during the runs. The development of the liquid morphology with increasing temperature $\left(850^{\circ} \mathrm{C}\right.$ to $\left.900^{\circ} \mathrm{C}\right)$ does not appear to have been affected by this contamination (Figures 7a-7c). Thus we conclude that the sodium contents are a useful indicator of interconnectivity but that the elevated levels of sodium did not cause the interconnectivity to occur in these experiments. In contrast, Watson and Brenan [1987] determined that increased salt contents in aqueous fluids can increase the likelihood of aqueous fluid interconnectivity.

The crystallographically controlled, interconnected liquid morphologies in our experiments indicate that dihedral angles $<60^{\circ}$ may not be necessary to achieve liquid interconnectivity. In addition, once interconnectivity is achieved, the average throat diameter of the liquid network will be larger than that in a dihedral angle-controlled (isotropic) system, leading to decreased tortuosity and thus increased permeability [Wolf, 1992]. Faul et al. [1990] also found that permeability may be enhanced by the presence of faceted faces in the partially melted olivine-basalt system. In our experiments, liquid forms along $\mathrm{Hb} / \mathrm{Pl}$ interfaces. Because the amphibolite itself is lineated, with elongated plagioclase crystals touching each other to form a semicontinuous network (i.e., a plagioclase-supported network within a hornblende matrix), the liquid that forms along the plagioclase surfaces becomes interconnected more readily than if the plagioclase crystals were isolated from one another. Thus the texture of the melting rock, as well as its mineralogy, plays a role in determining whether liquid interconnectivity and segregation occur.

Much longer experimental durations are needed to assess the further textural development and relevance of these experiments to natural systems. It is possible that our interpretation of the textures and chemical data may be valid only for experiments or for natural systems that develop over similar time periods, i.e., geologically instantaneous melting events such as those occurring near dikes and plutons and the injection of basaltic magmas into the lower crust. However, it seems logical (and based on our and others' experimental observations) that during melting, liquid morphology proceeds from nonconnected pockets to an interconnected network; once this texture is developed, there is no driving force in a system dominated by anisotropic minerals to disconnect the pockets unless the liquid is expelled and the rock matrix collapses. Waff and Faul [1992] noted that flat crystal/liquid interfaces are common even in texturally equilibrated olivine-melt systems. Recently, Laporte and Provost [1994] and Laporte [1994] have obtained data that support our results: that significant interfacial energy anisotropies exist even in simple quartz-bearing systems and that dihedral angle measurements may not be useful for determining liquid interconnectivity at low liquid fractions. Thus we feel that our experimental data may be generally but cautiously applied to the process of amphibolite anatexis in the lower continental crust.

We have found that the dehydration melting of lineated amphibolite can produce an interconnected, hydrous, relatively low-viscosity liquid at a relatively low temperature $\left(2875^{\circ} \mathrm{C}\right)$ and liquid fraction (2-5 vol \%) [Wolf and Wyllie, 1991, 1994]. These results indicate that liquid segregation might be possible during amphibolite dehydration melting. But will it occur? Another important parameter is time: the liquid extraction time must be shorter than the combined heating and cooling times. Melting 
occurs on a very short timescale, relative to regional heating (orogenic) events. If the liquids do not coalesce and segregate before they are quenched, then only migmatites form (however, the presence of a migmatite does not preclude the extraction of a significant portion of the liquid that initially was present). On the other hand, the system might not attain chemical or textural equilibrium if extraction is rapid enough.

\section{Importance of Disequilibrium Processes in Natural Systems}

Chemical equilibrium generally has been thought to be an a priori consequence of the high temperatures and long durations achieved during anatexis. However, manifestations of disequilibrium melting have been found in natural rocks, and recognition of this condition, especially from trace element and isotopic studies, is becoming more common [e.g., Dougan, 1981; Mehnert and Büsch, 1982; Weber and Barbey, 1986; Naslund, 1986; Kaczor et al., 1988; Copeland et al., 1988; Sawyer, 1991; Maalфe, 1992; Harris et al., 1992; Srogi et al., 1993; Watt and Harley, 1993]. The common occurrence of inherited zircon and monazite in granitic rocks [e.g., Williams et al., 1983] indicates that trace element and isotopic equilibrium is rarely achieved completely during anatexis [Watson and Harrison, 1984]. The dynamic disequilibrium melting model of Iwamori [1993, p. 301] suggests that "disequilibrium processes may largely control chemical variations in igneous rocks." A better understanding of how disequilibrium affects liquid compositions may lead to better controls on melting/cooling rates and on the determination of P$T-t$ paths of migmatites. Because the degree of trace element disequilibrium depends on liquid-restite interaction, studies focusing on this process may yield information on the possibility and timing of liquid segregation during anatexis [e.g., Sawyer, 1991], on the efficacy of different segregation processes, and on the importance of chemical reequilibration during cooling [e.g., Fourcade et al., 1992].

\section{Relevance of Disequilibrium, Solid Amphibolite Experiments to Liquid Segregation}

The previous section mentions the potential for and examples of chemical (mostly trace element) disequilibrium in natural rock systems. It is not clear, however, that the textural disequilibrium of our experimentally derived samples described above is relevant during anatexis. If we can answer the question, "which is attained first, chemical or textural equilibrium?" then we may be able to determine the relevancy of our experimentally generated textures. Glass compositions from two sets of powder and solid amphibolite experiments run at different temperatures are compared in Table 1 . Considering the differences in reactivity between the powder and solid media and the resultant differences in mineralogies and modes (compare results of Wolf and Wyllie [1991] with those of Wolf and Wyllie [1994]), the compositional differences of the liquids are small, indicating that chemical equilibrium is approached in both sets of experiments. In contrast, the textures between the two types of experiments are dramatically different from one another (compare photomicrographs of Wolf and Wyllie [1991] with those of Wolf and Wyllie [1993]). Thus we conclude that major element chemical equilibrium is attained before textural equilibrium. In other words, textural disequilibrium but major element chemical equilibrium appear to be preserved by the liquid morphologies and compositions in our experiments. We have no experimental data, however, to indicate whether textural equilibrium will be attained before or after chemical equilibration of trace elements, which generally lags behind that of major elements [e.g., Watson and Harrison, 1984]. Wolf and London [1994] noted that the texture of the rock (the distribution of accessory minerals) might even control whether the addition of certain trace elements to the liquid is governed by near-equilibrium or disequilibrium processes.

The possibility that disequilibrium melting may be an important process during crustal anatexis strengthens the relevance of Wolf and Wyllie's [1991] $\mathrm{H}_{2} \mathrm{O}$ content and viscosity calculations that are based on the disequilibrium experiments using solid pieces of amphibolite. Owing to the widespread breakdown of hornblende throughout the rock but only the local formation of liquid along hornblende-plagioclase boundaries, it is possible that early forming liquid can be $\mathrm{H}_{2} \mathrm{O}$-rich or even briefly $\mathrm{H}_{2} \mathrm{O}$-saturated (additional $\mathrm{H}_{2} \mathrm{O}$ can be added to the liquid by the breakdown of hornblende not immediately associated with the liquid-producing reaction [Wolf and Wyllie, 1991, Figure 6] or by

Table 1. Comparison of Liquid Compositions From Powder and Solid Amphibolite Dehydration Melting Experiments at $1 \mathrm{GPa}$

\begin{tabular}{lrrrrrrrr}
\hline & $\begin{array}{r}\text { Run 120 } \\
\text { powder }\end{array}$ & $\begin{array}{c}\text { s.d. } \\
n=3\end{array}$ & $\begin{array}{r}\text { Run 124 } \\
\text { solid }\end{array}$ & $\begin{array}{c}\text { s.d. } \\
n=5\end{array}$ & $\begin{array}{r}\text { Run 134 } \\
\text { powder }\end{array}$ & $\begin{array}{r}\text { s.d. } \\
n=3\end{array}$ & $\begin{array}{r}\text { Run 133 } \\
\text { solid }\end{array}$ & $\begin{array}{c}\text { s.d. } \\
n=3\end{array}$ \\
\hline Temperature, ${ }^{\circ} \mathrm{C}$ & 850 & & 850 & & 1000 & & 1000 & \\
Time, days & 8 & & 21 & & 4 & & 4 & \\
$\mathrm{SiO}_{2}$ & 64.79 & 0.26 & 67.44 & 0.12 & 51.77 & 0.30 & 51.33 & 0.14 \\
$\mathrm{TiO}_{2}$ & 0.43 & 0.05 & 0.14 & 0.06 & 0.51 & 0.01 & 0.39 & 0.05 \\
$\mathrm{Al}_{2} \mathrm{O}_{3}$ & 19.07 & 0.09 & 18.50 & 0.10 & 20.95 & 0.07 & 21.27 & 0.08 \\
$\mathrm{FeO}_{\mathrm{MnO}}$ & 4.51 & 0.14 & 3.65 & 0.02 & 7.09 & 0.15 & 8.49 & 0.17 \\
$\mathrm{MgO}$ & 0.18 & 0.08 & 0.19 & 0.08 & 0.23 & 0.09 & 0.30 & 0.14 \\
$\mathrm{CaO}$ & 1.51 & 0.13 & 1.20 & 0.04 & 6.36 & 0.08 & 5.86 & 0.04 \\
$\mathrm{Na}$ & 7.95 & 0.03 & 7.43 & 0.05 & 11.50 & 0.16 & 10.95 & 0.04 \\
$\mathrm{~K}_{2} \mathrm{O}$ & 1.25 & 0.15 & 1.08 & 0.06 & 1.40 & 0.13 & 1.08 & 0.07 \\
& 0.29 & 0.06 & 0.41 & 0.03 & 0.17 & 0.03 & 0.24 & 0.02 \\
\hline
\end{tabular}

Standard deviations are of the mean of $\boldsymbol{n}$ analyses. 
the formation of garnet). A series of temperature versus $\mathrm{H}_{2} \mathrm{O}$ content and $\mathrm{H}_{2} \mathrm{O}$ activity diagrams illustrates hypothetical paths along which a pocket of liquid might follow (Figure 8). Note that on a temperature- $\mathrm{X}_{\mathrm{H}_{2} \mathrm{O}}$ diagram (Figure 8a), during melting of a noneutectic composition (most natural systems), there is a significant temperature interval containing crystals $(X)+$ liquid (L) + vapor (V), and owing to the positive slope and curvature of the $\mathrm{H}_{2} \mathrm{O}$-saturation boundary, the initial liquid produced from a hydrous mineral-bearing rock (with no excess $\mathrm{H}_{2} \mathrm{O}$ ) can be $\mathrm{H}_{2} \mathrm{O}$ saturated $(\mathrm{M})$. During relatively slow melting, the system would follow the $\mathrm{H}_{2} \mathrm{O}$-undersaturated path toward $\mathrm{E}$. During rapid hornblende breakdown, relative to liquid formation, the local system could follow the path toward $\mathrm{D}$, along the $\mathrm{H}_{2} \mathrm{O}$-saturation boundary, before returning to $\mathrm{E}$. This process could reoccur on a very localized scale, depending on the relative rates of hornblende breakdown and liquid formation (which might not necessarily be constants) and could even become cyclical (oscillating between $E$ and D) for a brief period of time (see below).

This transient process also can be schematically viewed on a temperature- $\mathrm{H}_{2} \mathrm{O}$ activity diagram (Figure $8 \mathrm{~b}$ ). Hornblende breakdown and garnet formation will add $\mathrm{H}_{2} \mathrm{O}$ to the local system, creating a gradient in $\mathrm{H}_{2} \mathrm{O}$ activity $\left(a_{\left[\mathrm{H}_{2} \mathrm{O}\right]}\right)$. If large enough, the increase in $a_{\left[\mathrm{H}_{2} \mathrm{O}\right]}$ along hornblende-plagioclase boundaries will cause melting at the $\mathrm{H}_{2} \mathrm{O}$-saturated solidus (arrow from D to WM curves), at temperatures lower than those predicted for dehydration melting (DM). This $\mathrm{H}_{2} \mathrm{O}$-saturated condition will cause more melting; subsequent formation of more liquid will reduce the $a_{\left[\mathrm{H}_{2} \mathrm{O}\right]}$ in the liquid until more $\mathrm{H}_{2} \mathrm{O}$ is delivered to the liquid from continued hornblende dehydration. Waters [1988] found that during dehydration melting of mafic rocks and formation of granulite-facies assemblages, local gradients in $a_{\left[\mathrm{H}_{2} \mathrm{O}\right]}$ may have been present during melting, with the liquid segregations acting as sinks for the volatiles. The natural evidence for the existence of these gradients implies that nonequilibrium conditions were sustained for geologically relevant durations and subsequently preserved in the rock records.

These periods in which the liquids are $\mathrm{H}_{2} \mathrm{O}$-rich may be important for segregation because of the very low liquid viscosities. Borrowing a term from evolution theoreticians, at low liquid fractions, the melting process may be thought of in terms of punctuated equilibrium. When viewed on a large scale (spatially and temporally), the melting process seems continuous, however, the system or subsystems may oscillate between $\mathrm{H}_{2} \mathrm{O}$ saturated and $\mathrm{H}_{2} \mathrm{O}$-undersaturated conditions, until the breakdown of the hydrous mineral ceases. Although possibly only a minor portion of the cycle, most of the small-scale liquid segregation may occur during relatively $\mathrm{H}_{2} \mathrm{O}$-richer, lowerviscosity conditions. This cyclicity may be akin to the cyclic processes of fluid generation, hydrof racturing, fluid migration, and crack healing that occur during dehydration events. Thus, in coarse-grained, natural rocks, disequilibrium (transient) processes might control liquid segregation during anatexis. An oscillatory melting nature might also lengthen the amount of time needed for accessory minerals to equilibrate with the liquid, because interaction between these phases depends on their contact, which depends on the liquid fraction and location of the accessory minerals within the rock.

\section{Liquid Segregation During Restite Compaction}

McKenzie [1985] has calculated the conditions and durations needed for liquid segregation during compaction of source rocks
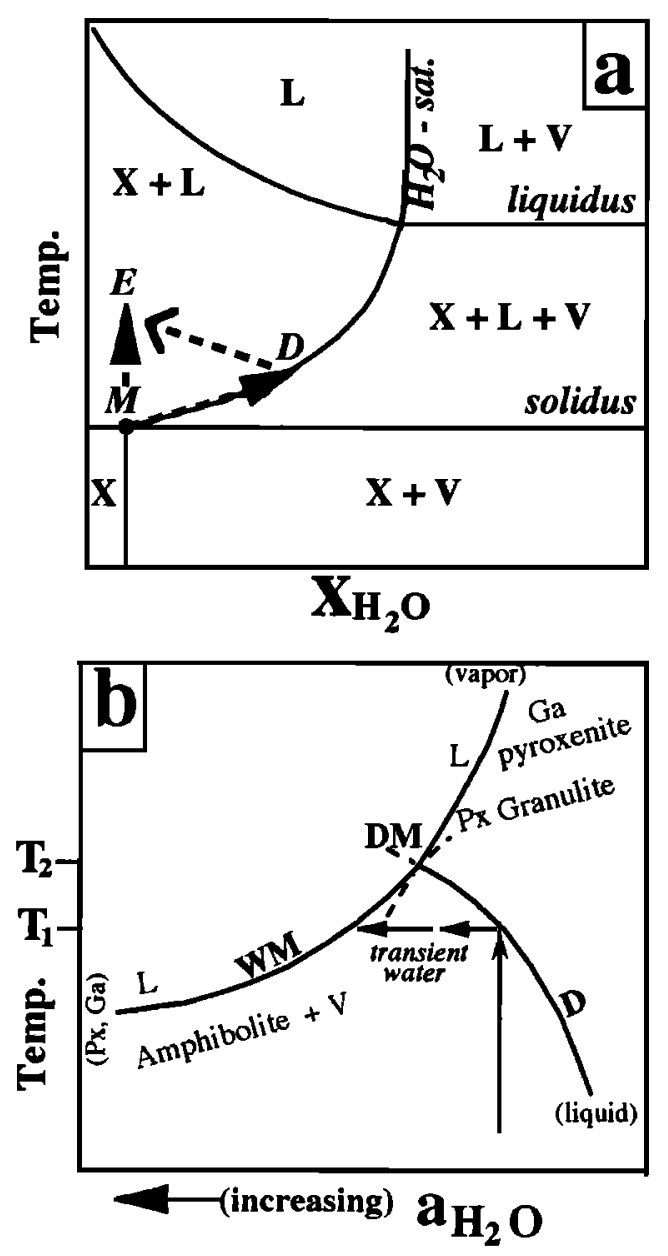

Figure 8. (a) Schematic temperature- $\mathrm{X}_{\left[\mathrm{H}_{2} \mathrm{O}\right]}$ diagram showing that the first trace of liquid produced by the breakdown of a hydrous mineral may be $\mathrm{H}_{2} \mathrm{O}$-saturated $(\mathrm{M})$. Slow heating will result in a path to $E$, but rapid heating and widespread breakdown of the hydrous mineral may result in continued $\mathrm{H}_{2} \mathrm{O}$-saturated conditions along path D. (b) Schematic $a_{\left[\mathrm{H}_{2} \mathrm{O}\right]}$ diagram showing the change from dehydration $\mathrm{D}$ to wet melting $\mathrm{WM}$ as a result of transient high $\mathrm{H}_{2} \mathrm{O}$ conditions during rapid hornblende breakdown. Phases that are absent from the reaction boundaries are shown in parentheses. Metastable extensions are dashed.

(with no additional noncoaxial deformation). Wolf and Wyllie [1991] applied McKenzie's [1985] equations to the behavior of the experimental liquids produced during amphibolite dehydration melting. Again, readers are cautioned about the application of these equations to complex experimental and natural systems. We still do not have reliable data from a range of bulk compositions for critical parameters such as liquid fractions, $\mathrm{H}_{2} \mathrm{O}$ contents, liquid viscosities, the role of textural development related to interconnectivity, regional heating rates in the deep crust, and strain rates. Noting the uncertainties inherent in such calculations and relying heavily on the disequilibrium liquid fractions and viscosities determined from the solid amphibolite experiments, Wolf and Wyllie [1991] calculated extraction of $12 \mathrm{vol} \%$ liquid from $100 \mathrm{~m}$ of amphibolite in $10^{5}$ years or from $1 \mathrm{~km}$ of amphibolite in $10^{6}$ years, at $875^{\circ} \mathrm{C}$. We have recalculated the compaction (i.e., segregation) times using the same equations but with data from our powder experiments (viscosity $\sim 10^{4} \mathrm{~Pa} \mathrm{~s}$, which is the approximate average for temperatures between 875 and $975^{\circ} \mathrm{C}$ in Figure 6 , and $X_{L} \sim 15$ vol 
$\%)$; the segregation times are only twice as long as those calculated from the solid amphibolite data, and they may still be less than the maximum duration of metamorphic-anatectic events, $10^{6}-10^{7}$ years [Wickham, 1987]. Segregation of liquid from thinner amphibolitic layers (1-10-m-thick) into small pods of migmatite can occur within $10^{3}-10^{4}$ years. Heating might be rapid enough for the proposed melting processes to occur and long enough for liquid segregation to occur (even from 100-1000 $\mathrm{m}$ thick layers of amphibolite) if the source of heat comes from the commonly invoked mechanism of basaltic magma injection into the base of the crust [Huppert and Sparks, 1988]. Furthermore, these calculations do not take into account the possibly dominant effect that tectonic deformation may have on the efficacy of segregation [e.g., Brown, 1994]

\section{Dehydration Melting-Enhanced Deformation and Melt Fracturing: Mechanical Effects of an Interconnected Liquid Network and a Transient $\mathrm{H}_{2} \mathrm{O}$-Saturated Liquid}

We have noted the possible importance that transient $\mathrm{H}_{2} \mathrm{O}$ saturated conditions may have in the segregation of liquids. In the presence of significant deviatoric stresses, $\mathrm{H}_{2} \mathrm{O}$-rich conditions can lead to increased localized deformation [Etheridge et al., 1984] which, in turn, can lead to increases in the efficacy of liquid segregation. Relatively low-temperature cataclastic deformation is dramatically enhanced by an increase in $\mathrm{P}_{\mathrm{H}_{2} \mathrm{O}}$ due to dehydration [Brodie and Rutter, 1985]. This dehydrationenhanced deformability may be important in amphibolites comprising subducting oceanic crust [e.g., Raleigh and Paterson, 1965]. Likewise, dehydration melting-enhanced deformation also may be important in oceanic and continental amphibolites [Wolf, 1992]; Flagler and Spray [1991] found evidence for melting along hydrated, low-angle shear zones within the layer 3 gabbros in oceanic crust. Other field studies describing fluidenhanced migmatization and liquid segregation during ductile shearing are common [e.g., Mogk, 1992; Allibone and Norris, 1992]. On the basis of rock deformation experiments, Rushmer [1994] concluded that melting-induced embrittlement (cataclasis) may be an important but transient deformation process during the early stages of amphibolite anatexis.

In the presence of minimal deviatoric stresses, $\mathrm{H}_{2} \mathrm{O}$-rich conditions still can increase the efficacy of liquid segregation through hydrofracturing or, more appropriately named, melt fracturing, in the case in which a silicate liquid is present. Walther and Orville [1982] suggested that hydraulic fracturing can occur during dehydration. The presence of hydrothermal veins implies that $P_{\mathrm{H}_{2}} \mathrm{O}$ can be $\geq \mathrm{P}_{\mathbf{O}_{3}}$ (at least instantaneously, where $\sigma_{3}$ is the minimum effective stress) even under highpressure (2 GPa) conditions [Selverstone et al., 1990]. Liquid injection by extensional fracture can occur at any depth when the liquid pressure approaches the confining pressure, $\mathrm{P}_{\mathrm{O}_{3}}$, and the effective stress approaches zero [e.g., Shaw, 1980].

The interconnectedness of a liquid network may cause melt fracturing in a partially melted system. Using the relatively straightforward hydrofracturing model of Nicolas [1990], $\Delta \mathrm{P}=$ $\mathrm{g} \times \Delta \rho \times \mathrm{h}$, we calculate a liquid overpressure $(\Delta \mathrm{P})$ to be about 1 $\mathrm{MPa}$ (10 bars) in a 100-m-thick partially melted region (where $\mathrm{g}$ is the gravitational constant, $\Delta \rho$ is the density contrast between garnetiferous restite and liquid $\left(1100 \mathrm{~kg} / \mathrm{m}^{3}\right.$ [Wolf and Wyllie, 1993]), and $h$ is the interconnected liquid column height). If compressive or tensile stresses are negligible, then melt fracturing will occur when the liquid pressure reaches the tensile strength of the rock. The tensile strength of partially melted basalt (with a very low liquid fraction) is about $1 \mathrm{MPa}$ [Shaw, 1980], and thus melt fracturing is possible if the liquid network is interconnected throughout the 100-m-thick layer of partially melted basalt, regardless of the actual depth (and pressure) of this layer. This rough calculation does not take into account the positive change in volume that occurs during dehydration melting and that would enhance the fracturing process. Melt fracturing and the subsequent pressure depression (which would suck liquid into the fracture) may be very efficient at segregating a liquid from its source [e.g., Sleep, 1988; Nicolas, 1990; Clemens and Mawer, 1992].

The transient $\mathrm{H}_{2} \mathrm{O}$-saturated liquid inferred from our dehydration melting experiments may be an additional catalyst for melt fracturing, above that due to $\Delta P$. Slight fluctuations in pressure might occur due to the cyclical nature of the dehydration melting process (described above). The mechanical effect of the generation of a transient $\mathrm{H}_{2} \mathrm{O}$-saturated (or even $\mathrm{H}_{2} \mathrm{O}$ oversaturated) liquid might be analogous to the larger-scale effect caused during retrograde boiling (vapor exsolution) during the final stages of magma crystallization, during which $P_{v a p o r} \geq P_{\sigma_{3}}$, and cracking of the country rock carapace produces dikes. Volatile exsolution at the tip of the propagating liquid-filled fracture may enhance fracturing and liquid segregation during the early stages of anatexis [e.g., Clemens and Mawer, 1992]. The earlier forming liquid may be too hydrous to ascend very far without crossing its solidus, but dehydration of this liquid (through reaction with the wall rocks or crystallization of hydrous minerals) or resupply and mixing of later forming drier liquids (Figure 5) might mitigate this potential problem. In order for the subsequent ascent of the deeply generated liquid to take place, coalescence of the liquid from these relatively small veins into larger dikes must occur [e.g., Sleep, 1988; Takada, 1989].

\section{Summary}

1. Within the stability field of garnet, amphibolite dehydration melting can occur at relatively low temperatures in the lower continental crust $\geq 1 \mathrm{GPa}$, so there is no need to call upon unreasonably high temperatures or unusual circumstances to promote anatexis. The amphibolite dehydration melting solidus may drop as low as the $\mathrm{H}_{2} \mathrm{O}$-saturated solidus, but the amount of liquid produced will be less than that generated during $\mathrm{H}_{2} \mathrm{O}$ saturated melting, until high temperatures $\left(1000^{\circ} \mathrm{C}\right)$ and high liquid fractions $\left(X_{L} \sim 0.5\right)$ are reached.

2. Liquid interconnectivity can be achieved during amphibolite dehydration melting at $<900^{\circ} \mathrm{C}$ with $<5$ vol \% liquid, under some circumstances. The formation of interconnected, open-throated, liquid pockets is crystallographically controlled by the abundance of structurally anisotropic hornblende. The lineated texture of the amphibolite may aid interconnectivity by providing semi-continuous hornblende-plagioclase surfaces along which subsequent melting occurs.

3. Liquids equilibrated with the restitic mineral assemblage can be hydrous $\left(24 \mathrm{wt} \% \mathrm{H}_{2} \mathrm{O}\right)$ and have low viscosities $\left(10^{3}-10^{4}\right.$ Pa s).

4. If it occurs in nature, rapid breakdown of hornblende could lead to the formation of temporarily $\mathrm{H}_{2} \mathrm{O}$-rich or $\mathrm{H}_{2} \mathrm{O}$-saturated liquids with even lower viscosities $\left(\sim 10^{2} \mathrm{~Pa} s\right)$. These transient (possibly cyclical) conditions may be only a minor part of the anatectic process but may play an important role in the segregation of the liquids.

5. Liquid segregation might be possible (i.e., segregation times < heating times + cooling times) even in the absence of 
tectonic deformation (which would further decrease segregation times).

6. The transient high liquid pressure could increase segregation rates by enhancing localized deformation (liquidfilled shear zones) or by triggering melt fracturing (liquid-filled veins).

Acknowledgments. This research was supported by the Earth Science section of NSF, grant EAR 89-04375. We thank A. Patiño Douce, D. Laporte, and T. Rushmer for their thoughtful reviews.

\section{References}

Allibone, A. H., and R. J. Norris, Segregation of leucogranite microplutons during syn-anatectic deformation: an example from the Taylor Valley, Antarctica, J. Metamorph. Geol., 10, 589-600, 1992.

Arth, J. G., and F. Barker, Rare-earth partitioning between hornblende and dacitic liquid and implications for the genesis of trondhjemitictonalitic magmas, Geology, 4, 534-536, 1976.

Barker, F., Trondhjemite: Definition, environment and hypotheses of origin, in Trondhjemites, Dacites and Related Rocks, edited by F. Barker, pp. 1-12, Elsevier, New York, 1979.

Beard, J. S., and G. E. Lof gren, Dehydration melting and water-saturated melting of basaltic and andesitic greenstones and amphibolites, $J$. Petrol., 32, 365-401, 1991.

Brodie, K. H., and E. H. Rutter, On the relationship between deformation and metamorphism, with special reference to the behavior of basic rocks, in Metamorphic Reactions, Adv. Phys. Geochem, vol. 4, edited by A. B. Thompson and D. C. Rubie, pp. 138-179, Springer-Verlag, New York, 1985.

Brown, M., The generation, segregation, ascent and emplacement of granite magma: The migmatite-to-crustally-derived granite connection in thickened orogens, Earth Sci. Rev., 36, 83-130, 1994.

Bulau, J. R., H. S. Waff, and J. A. Tyburczy, Mechanical and thermodynamic constraints on fluid distribution in partial melts, $J$. Geophys. Res., 84, 6102-6108, 1979.

Clemens, J. D., and C. K. Mawer, Granitic magma trausport by fracture propagation, Tectonophysics, 204, 339-360, 1992.

Copeland, P., T. M. Harrison, R. R. Parrish, B. C. Burchfiel, and K. V. Hodges, Identification of inherited-radiogenic $\mathrm{Pb}$ in monazite and its implications for U-Pb systematics, Nature, 333, 760-763, 1988.

Deniel, C.. P. Vidal, A. Ferndanez, P. Le Fort, and J. J. Peucat, Isotopic study of the Manaslu granite (Himalaya, Nepal): Inferences of the age and source of Himalayan leucogranites, Contrib. Mineral. Petrol., 96, 78-92, 1987.

Dougan, T. W., Melting reactions and trace element relationships in selected specimens of migmatitic pelites from New Hampshire and Maine, Contrib. Mineral. Petrol., 78, 337-344, 1981.

Eggler, D. H., Principles of melting of hydrous phases in silicate melt. Yearbook Carnegie Inst. Washington, 72, 491-495, 1973.

Etheridge, M. A., V. J. Wall, S. F. Cox, and R. H. Vernon, High fluid pressures during regional metamorphism and deformation: Implications for mass transport and deformation mechanisms, $J$. Geophys. Res., 89, 4344-4358, 1984.

Faul, U. H., H. S. Waff, and J. Chambers, Refined experimental determination of wetting angles in olivine-basalt partial melts (abstract), Eos Trans. AGU, 71, 1720, 1990.

Flagler, P. A., and J. G. Spray, Generation of plagiogranite by amphibolite anatexis in oceanic shear zones, Geology, 19, 70-73, 1991.

Fourcade, S., H. Martin, and J. de Brémond d'Ars, Chemical exchange in migmatites during cooling, Lithos, 28, 43-53, 1992.

Harris, N. B. W., P. Gravestock, and S. Inger, Ion-microprobe determinations of trace-element concentrations in garnets from anatectic assemblages, Chem. Geol., 100, 41-49, 1992.

Helz, R. T., Phase relations of basalts in their melting range at $\mathrm{P}_{\mathrm{H}_{2}} \mathrm{O}=5$ kb, Part II, melt compositions, J. Petrol., 17, 139-193, 1976.

Holloway, J. R., and C. W. Burnham, Melting relations of basalt with equilibrium water pressure less than total pressure, J. Petrol., 13, 1-29, 1972.

Huppert, H. E., and R. S. J. Sparks, The generation of granitic magmas by intrusion of basalt into continental crust, J. Petrol, 29, 599-624, 1988.

Iwamori, H., Dynamic disequlibrium melting model with porous flow and diffusion-controlled chemical equilibrium, Earth Planet. Sci. Lett., 114, 301-313, 1993.

Jurewicz, S. R., and E. B. Watson, Distribution of partial melt in a felsic system: The importance of surface energy, Contrib. Mineral. Petrol., 85, 25-29, 1984.

Kaczor, S. M., G. N. Hanson, and Z. E. Peterman, Disequilibrium melting of granite at the contact with a basic plug: Geochemical and petrographic study, J. Geol., 96, 61-78, 1988.

Lambert, I. B., and P. J. Wyllie, Melting of gabbroic (quartz eclogite) with excess water to 35 kilobars, with geological applications, $J$. Geol., 80, 693-708, 1972.

Laporte, D., Wetting behavior of partial melts during crustal anatexis: The distribution of hydrous silicic melts in polycrystalline aggregates of quartz, Contrib. Mineral. Petrol., 116, 486-499, 1994.

Laporte, D., and A. Provost, The equilibrium crystal shape of silicates: Implications for the grain-scale distribution of partial melts (abstract), Eos Trans. AGU, 75(16), Spring Meeting suppl., 364, 1994.

Maaløe, S., Melting and diffusion processes in closed-system migmatization, J. Metamorph. Geol., 10, 503-516, 1992.

McKenzie, D. P., The extraction of magma from the crust and mantle, Earth Planet. Sci. Lett., 74, 81-91, 1985.

Mehnert, K. R., and W. Busch, The initial stage of migmatite formation, Neues Jahrb. Mineral. Abh., 145, 211-238, 1982.

Mogk, D. W., Ductile shearing and migmatization at mid-crustal levels in an Archaean high-grade gneiss belt, northern Gallatin Range, Montana, USA, J. Metamorph. Geol., 10, 427-438, 1992.

Naslund, H. R., Disequilibrium partial melting and rheomorphic layer formation in the contact aureole of the Basistoppen sill, East Greenland, Contrib. Mineral. Petrol., 93, 359-367, 1986.

Nicolas, A., Melt extraction from mantle peridotites: Hydrofracturing and porous flow, with consequences for oceanic ridge activity, in Magma Transport and Storage, edited by M. P. Ryan, pp. 159-173, John Wiley, New York, 1990.

Raleigh, C. B., and M. S. Paterson, Experimental deformation of serpentinite and its tectonic implications, J. Geophys. Res., 70, 39653985, 1965.

Rapp, R. P., E. B. Watson, and C. F. Miller, Partial melting of amphibolite/eclogite and the origin of Archean trondhjemites and tonalites, Precambrian Res, 51, 1-25, 1991.

Robertson, J. K., and P. J. Wyllie, Rock-water systems, with special reference to the water-deficient region, Am. J. Sci., 271, 252-277, 1971.

Robinson, P., Metamorphosed igneous rocks at high temperature: The breakdown of amphiboles, in Amphiboles: Petrology and Experimental Phase Relations, edited by D. R. Veblen and P. H. Ribbe, pp. 182-210, Mineralogical Society of America, Rev. Mineral., vol. 9B, Washington, D. C., 1982.

Rushmer, T., Partial melting of two amphibolites: Contrasting expeirmental results under fluid-absent conditions, Contrib. Mineral. Petrol., 107, 41-59, 1991.

Rushmer, T., Deformation by fracture in the presence of melt: An experimental test (abstract), Eos Trans. AGU, 75(16). Spring Meeting suppl., 362, 1994.

Sawyer, E. W., Disequilibrium melting and rate of melt-residuum separation during migmatization of mafic rocks from the Grenville Front, Quebec, J. Petrol., 32, 701-738, 1991.

Selverstone, J., G. Franz, and S. Thomas, Fluids at high pressure: Inferences from $20 \mathrm{kbar}$ eclogites and associated veins in the Tauern Window, Austria, Goldschmidt Conference, Baltimore, MD, 1990.

Shaw, H. R., Viscosities of magmatic silicate liquids: An empirical method of prediction, Am. J. Sci., 272, 870-893, 1972.

Shaw, H. R., The fracture mechanisms of magma transport from the mantle to the surface, in Physics of Magmatic Processes, edited by $\mathbf{R}$. B. Hargraves, pp. 201-264, Princeton University Press, Princeton, New Jersey, 1980. 
Sleep, N. H., Tapping of melt by veins and dikes, J. Geophys. Res., 93, $10,255-10,272,1988$

Srogi, L., M. W. Wagner, and T. M. Lutz, Dehydration partial melting and disequilibrium in the granulite-facies Wilmington Complex, Pennsylvania-Delaware piedmont, Am. J. Sci., 293, 405-462, 1993.

Takada, A., Magma transport and reservoir formation by a system of propogating cracks, Bull. Volcanol., 52, 118-126, 1989.

Thompson, A. B., Dehydration melting of crustal rocks, Rend. Soc. Min. Petrol. Ital., 43, 41-60, 1988.

Waff, H. S., and J. R. Bulau, Experimental studies of near-equilibrium textures in partially molten silicates at high pressures, Adv. Earth Planet. Sci., 12, 229-236, 1982.

Waff, H. S., and U. H. Faul, Effects of crystalline anisotropy on fluid distribution in ultramafic partial melts. J. Geophys. Res., 97, 90039014, 1992.

Walther, J. V., and P. M. Orville, Volatile production and transport in regional metamorphism, Contrib. Mineral. Petrol., 79, 133-145, 1982.

Waters, D. J., Partial melting and the formation of granulite facies assemblages in Namaqualand, South Africa, J. Metamorph. Geol., 6, 387-404, 1988.

Watson, E. B., Melt infiltration and magma evolution, Geology, 10, 236240, 1982

Watson, E. B., and J. M. Brenan, Fluids in the lithosphere, 1. Experimentally-determined wetting characteristics of $\mathrm{CO}_{2}-\mathrm{H}_{2} \mathrm{O}$ huids and their implications for fluid transport, host-rock physical properties, and fluid inclusion formation, Earth Planet. Sci. Lett., 85 , 497-515, 1987.

Watson, E. B., and T. M. Harrison, Accessory minerals and the geochemical evolution of crustal magmatic systems: A summary and prospectus of experimental approaches, Phys. Earth Planet. Inter., 35. 19-30, 1984

Watt, G. R., and S. L. Harley, Accessory phase controls on the geochemistry of crustal melts and restites produced during waterundersaturated partial melting, Contrib. Mineral. Petrol., 114, 550566, 1993.

Weber, C., and P. Barbey, The role of water, mixing processes and metamorphic fabric in the genesis of the Baume migmatites (Ardèche, France), Contrib. Mineral. Petrol., 92, 481-491, 1986.

Wickham, S. M., The segregation and emplacement of granitic magmas, J. Geol. Soc. London, 144, 281-297, 1987.

Williams, I. S., W. Compston, and B. W. Chappell, Zircon and monazite
$\mathrm{U}-\mathrm{Pb}$ systems and the histories of I-lype magmas, Berridale batholith, Austr. J. Petrol., 24, 76-97, 1983.

Williams, M. L., and S. K. Hanmer, Syntectonic generation of felsic magma from partial melting of wet mafic dikes in the lower crust, northern Saskatchewan (abstract), Eos Trans. AGU, 75(16), Spring Meeting suppl., 362, 1994.

Winther, K. T., and R. C. Newton, Experimental melting of hydrous low$\mathrm{K}$ tholeiite: Evidence on the origin of Archean cratons, Bull. Geol. Soc. Den., 39, 213-228, 1991.

Wolf, M. B., Amphibolite-tonalite relationships, I, Experimental investigation of the phase relationships and textural development of amphibolite dehydration melting; II, The geology, petrology and geochronology of a tonalitic and mafic dike swarm (southwestern Foothills Terrane, California), Ph.D. thesis, Calif. Inst. of Technol., Pasadena, 1992.

Wolf, M. B., and D. London, Apatite dissolution into peraluminous haplogranitic melts: An experimental study of solubilities and mechanisms, Geochim. Cosmochim. Acta, 58, 4127-4145, 1994.

Wolf, M. B., and P. J. Wyllie, Dehydration-melting of solid amphibolite at $10 \mathrm{kbar}$ : Textural development, liquid interconnectivity and applications to the segregation of magmas, Mineral. Petrol., 44, 151$179,1991$.

Wolf, M. B., and P. J. Wyllie, Garnet growth during amphibolite anatexis: Implications of a garnetiferous restite, J. Geol., 101, 357373, 1993.

Wolf, M. B., and P. J. Wyllie, Dehydration-melting of amphibolite at 10 kbar. The effects of temperature and time, Contrib. Mineral. Petrol., 115, 369-383, 1994.

Wyllie, P. J., and M. B. Wolf, Amphibolite dehydration melting: Sorting out the solidus, in Magmatic Processes and Plate Tectonics, edited by H. M. Prichard, T. Alabaster, N. B. W. Harris, and C. R. Neary, Geol. Soc. Spec. Publ. London, 76, 405-416, 1993.

M. B. Wolf, School of Geology and Geophysics, University of Oklahoma, Norman, OK 73019. (e-mail: mwolf@gcn.uoknor.edu)

P. J. Wyllie, Division of Geological and Planetary Sciences, California Institute of Technology, Pasadena, CA 91125.

(Received July 15, 1994; revised January 13, 1995;

accepted February 24, 1995.) 